\title{
O retorno do imortal: D. Pedro I mitificado pelos militares nas representações imagéticas das Revistas O Cruzeiro e Manchete no Sesquicentenário da Independência (1972)
}

\begin{abstract}
Resumo
Este artigo intenciona problematizar as imagens veiculadas nas revistas $O$ Cruzeiro e Manchete no ano do Sesquicentenário da Independência do Brasil. Neste evento comemorativo, a figura do monarca D. Pedro I, representante da "unificação do país", fica evidenciada nos anais da história pátria, após um acordo diplomático luso-brasileiro e a chegada de parte do corpo do Imperador ao Brasil, com exceção do coração, deixado por ele em testamento à cidade do Porto. A estratégia do regime militar brasileiro em conduzir D. Pedro I à virtude por meio da reelaboração positiva de sua figura está relacionada às suas façanhas militares realizadas no comando do exército liberal em Portugal, a partir de 1828, quando luta contra o governo absolutista de seu irmão, D. Miguel. As representações imagéticas do traslado ao Brasil de seus restos mortais, em abril de 1972, no governo do General Médici, demonstram a simbologia dos elementos de memória evocados pela política do Estado autoritário, sedenta por atos comemorativos e envolta em cerimoniais de cunho espetacular. A ampla divulgação veiculada pelas revistas está vinculada a uma clara intenção dos militares em apropriar-se de atos comemorativos para mitificar a figura de D. Pedro I no panteão dos heróis nacionais, a partir da utilização de aspectos da história pátria e arsenais imagéticos carregados de significados propulsores da memória.
\end{abstract}

Palavras-chave: Representações imagéticas; D. Pedro I; Memória; O Cruzeiro; Manchete.

\section{Cristina Ferreira}

Doutoranda em História Social pela UNICAMP. Mestre em História do Brasil pela Universidade Federal de Santa

Catarina. Professora titular da Fundação Universidade Regional de Blumenau - FURB. cliocris@gmail.com

\footnotetext{
Evander Ruthieri Saturno da Silva Mestrando no Programa de PósGraduação em História da Universidade Federal do Paraná. Licenciado e bacharel em História pela Universidade Regional de Blumenau -

FURB.evanderdoc@hotmail.com
}

\section{Para citar este artigo:}

FERREIRA, Cristina; SILVA, Evander Ruthieri Saturno da. O RETORNO DO IMORTAL: D. Pedro I mitificado pelos militares nas representações imagéticas das Revistas $O$ Cruzeiro e Manchete no Sesquicentenário da Independência (1972). Revista Tempo e Argumento, Florianópolis, v. 6, n.11, p. 355-385, jan./abr. 2014.

DOI: $10.5965 / 2175180306112014355$

http: //dx.doi.org/10.5965/2175180306112014355 
The return of the immortal: $D$.

Pedro I mythologized by the

military in the imagistic

representations of $O$ Cruzeiro and

Manchete magazines in

Independence Sesquicentennial

\title{
(1972)
}

\begin{abstract}
This article intends to discuss the images conveyed in $O$ Cruzeiro and Manchete magazines, during the year of the Independence Sesquicentennial of Brazil. In this commemorative event, the figure of the monarch $\mathrm{D}$. Pedro I, representative of the "country's unification", is evident in the annals of national history after a LusoBrazilian diplomatic agreement and the arrival of the Emperor's body to Brazil, with the exception of the heart, left in his will to the city of Porto. The strategy of the Brazilian military regime in elevate D. Pedro I to the virtue through a positive reworking of his character, is related to his military exploits performed in command of the liberal army in Portugal in 1828, when he fought against the absolutist government of his brother, D. Miguel. The imagistic representations of the transfer of his remains to Brazil, in April 1972, during the government of General Medici, show the symbolism of memory elements evoked by the authoritarian state's politics, thirsty for commemorative events and wrapped in ceremonials of spectacular nature. The wide dissemination conveyed by the magazines is linked to a clear intention of the military to take ownership of commemorative events to mystifi the figure of D. Pedro $I$ in to the pantheon of national heroes, from the wide use of aspects of national history and imagery resources charged with meanings able to thrust memory.
\end{abstract}

Keywords: Imagistic representations; D. Pedro I;

Memory; O Cruzeiro; Manchete. 


\section{Introdução}

O ano de 1972 foi marcado pelo Sesquicentenário da Independência do Brasil, evento largamente utilizado pelo governo autoritário vigente no período para demarcar práticas culturais, com o propósito de justificar a contemporaneidade ditatorial, posta como desvinculada das formas de governo entendidas como populistas, para promover o desenvolvimentismo, em nome da recuperação de princípios "democráticos e cristãos". A configuração deste processo histórico envolve o investimento maciço dos militares na construção de heróis nacionais, selecionados e promovidos em nome da geração de uma memória oficial e institucionalizada, capaz de personificar um passado sugestivo de uma continuidade nas lideranças militares.

Atenção redobrada recaiu sobre a personagem de D. Pedro I, sobretudo por conta dos símbolos e alegorias elaborados durante as comemorações do Sesquicentenário da Independência. Até então, o Imperador era integrante do panteão de heróis nacionais, porém, tornou-se oportuno frisar sua característica como personagem dotada de forte caráter militar. Esta situação possibilitou ao governo militar envidar esforços, na tentativa de recorrer a uma institucionalização do mito do "imortal” D. Pedro I, levada a cabo por meio da sacralização do corpo do monarca, mediante o traslado de seus restos mortais para o Brasil.

Este projeto governista envolve a aproximação entre Brasil e Portugal, por meio de uma espécie de reciprocidade histórica e suas representações imagéticas, as quais foram veiculadas em periódicos de expressiva circulação nacional, a exemplo das edições comemorativas das Revistas $O$ Cruzeiro e Manchete, foco de análise e problematização do texto, que ora se apresenta. A produção e a difusão das tramas imagéticas em torno da figura de D. Pedro I por intermédio destas publicações estão imbricadas às festividades dos cento e cinquenta anos da Independência do Brasil. Além disso, as imagens integram e referenciam a "maquinaria" festiva dos militares e seus usos da história pátria, no afã de apropriar-se de eventos cívicos para fazer valer o lema de "comemorar para bem perpetuar" e legitimar a memória constituída em torno de heróis militares. 


\section{O Imperador D. Pedro I entre a História e a Memória}

As tramas imagéticas estão relacionadas a múltiplos usos, sobretudo, em momentos de implantação de novas ordens políticas, instantes nos quais muitas das tensões convergem para a legitimação de memórias, ou para a promoção do esquecimento (TURAZZI, 2006, p.229). A problematização e análise da figura de D. Pedro I, herói nacional cultuado pelos militares, entre a história e a memória, conectase diretamente com as representações imagéticas e seus "componentes culturais, estéticos e ideológicos constituintes de sua elaboração e recepção" (KOSSOY, 2007, p.17). Logo, a imagem não pode ser entendida como um documento objetivo ou transmissor de uma realidade absoluta, mas carrega consigo uma evidência documental, estratagema típico do sistema de representação, que estabelece um vínculo com o material e com o real. Por conseguinte, cabe analisar as evidências presentes na imagem, decodificar sua linguagem técnico-estética e as "representações da realidade histórica, ou social nelas contidas" (NAPOLITANO, 2010, p.238).

A reelaboração de imagens positivas em torno de figuras ilustres representativas de um passado sugestivo da continuidade de lideranças militares permeia os intentos políticos dos presidentes militares, particularmente do General Médici, que governou o Brasil de 1969 a 1974. Os elementos da memória evocados neste período são expressos nas representações imagéticas de seus líderes políticos e na seleção de seus heróis, em vias de perpetuá-los por meio de desfiles cívicos, ou datas comemorativas. Nestes termos, o tratamento delegado às imagens produzidas durante o regime militar busca contemplar as tramas constituintes de seu estatuto de veracidade, com o fito de produzir significações pautadas em um universo simbólico, ou alegórico capaz de incorporar elementos militares configurados na memória de aspectos da história pátria.

A análise em questão está circunscrita nas representações imagéticas veiculadas em publicações de expressiva circulação no país: as revistas O Cruzeiro e Manchete. Ao difundirem imagens dos heróis nacionais e das lideranças políticas da ditadura militar, estas revistas conectam-se, propositadamente ou não, ao projeto de constituição de uma história calcada em figuras míticas e vultos ilustres. O envolvimento de uma parcela da imprensa nacional com os festejos idealizados pelo governo autoritário demonstra parte 
da experiência de colaboracionismo, empreendida por alguns veículos de comunicação, em relação aos esforços ditatoriais em projetar imagens de uma memória nacional, pautada na legitimação da contemporaneidade por meio de datas comemorativas e desfiles cívicos, a exemplo do Sesquicentenário da Independência, em 1972, como um momento capaz de mobilizar significativa parcela da população brasileira.

Os investimentos dos militares convergem para enaltecer, ou reavivar estas datas comemorativas e promover a difusão de imagens de determinadas personagens históricas, com o intuito de cultivar um passado heroico representativo da "liturgia do poder" (FICO, 1997, p.54) que cerca os intentos ditatoriais. Esta liturgia do poder se manifesta na constituição de símbolos, mitos e ritos, os quais buscam perpetuar uma história comum e exercer um papel de integração, de modo a reforçar o sentimento de pertencimento ao grupo e ofertar suporte à construção de valores que o tornam coeso e legítimo.

A investigação das produções imagéticas pode ser realizada por meio das representações, dada sua proposição teórica que relaciona uma imagem presente e um objeto ausente, e "faz com que se tome o engodo pela verdade, que considera os signos visíveis como índices seguros de uma realidade que não o é” (CHARTIER, 1990, p.20). Visivelmente o termo "representações" não comporta em sua aplicação a ideia equivocada de tomá-lo como uma espécie de bloco unívoco, até porque se encontra no plural. Portanto, convém frisar que o conceito de "representação" requer atenção à multiplicidade de sentidos vinculados às classificações, divisões e delimitações que organizam o mundo social e os esquemas intelectuais, por meio dos quais o presente adquire sentido e o espaço é decifrado. A referência conceitual indicada por Roger Chartier, em resposta à crise vivenciada pela História no final dos anos 1980 frente às ideias pós-modernas de que tudo seria discurso, não remete, exclusiva ou necessariamente, às imagens no sentido aqui proposto (fotos das revistas), mas se refere aos embates entre agentes e instituições. Sua aplicação como recurso teórico ocorre, neste caso, em observância ao fato de que tais disputas de representações se estabelecem em função de um "paradoxal entrecruzamento de restrições transgredidas e de liberdades restringidas" (CHARTIER, 2001, p. XIII). 
Por se tratar de uma conjuntura marcada pelo autoritarismo, as representações de heróis da história pátria, difundidas em revistas e periódicos, buscam desempenhar um papel pedagógico de acentuado caráter narrativo e alegórico (LIMA; CARVALHO, 2011, p.17), no afã de legitimar a contemporaneidade ditatorial. Portanto, as representações não são discursos neutros, pois produzem estratégias e práticas "que tentam impor uma autoridade à custa de outro", com a finalidade de "legitimar um projeto reformador, ou justificar, para os próprios indivíduos, as suas escolhas e condutas" (CHARTIER, 1990, p.17). As representações imagéticas dos heróis nacionais produzidas pela ditadura militar demonstram os esforços do governo autoritário em permanentemente lembrar-se dos feitos passados "como caminho para encontrar um lugar no presente" (GUIMARÃES, 2007, p.26), intento envolto na seleção e promoção de mitos, ritos e símbolos.

Estes movimentos ligados à constituição de personagens heroicos no Brasil estão, em meados do século XIX, vinculados ao Instituto Histórico e Geográfico Brasileiro (IHGB), instituição responsável pela difusão de vultos históricos e 'homens ilustres'. Promovidos em dicionários biográficos, os 'homens ilustres' do século XIX apresentam o perfil de sábios e legisladores, indivíduos amáveis, em oposição a reis, santos ou heróis (ENDERS, 2000, p.25). As comemorações e os festejos após a Proclamação da República, em 1889, elencam Joaquim José da Silva Xavier, o Tiradentes, como personagem significativa na consolidação do regime republicano no Brasil (CARVALHO, 1993, p.71-72). Esta escolha ocorre em detrimento de outras figuras, a exemplo de D. Pedro I, referenciado com reservas e associado à Monarquia e aos seus excessos. Embora Osório Duque-Estrada, durante a Primeira República, tenha pretendido perpetuar a imagem do primeiro monarca no Hino Nacional, pouco menciona o Imperador em seus escritos (BITTENCOURT, 1988, p.54). Entre os militares do exército, a institucionalização do culto ao "patrono", Duque de Caxias, ocorre a partir de 1923, por meio de uma proposta fomentada pelo IHGB (CASTRO, 2000, p.105).

Tais personagens heroicos tornam-se associados a determinadas datas comemorativas oficialmente instituídas e evidenciam o culto à memória, ou o cultivo do esquecimento, que cerca os vultos ilustres durante o século XX. Nestes termos, a comemoração do Sete de Setembro entre os republicanos busca enfatizar a conquista da 
liberdade, e não a imagem de D. Pedro I propriamente dita que, em geral, até então era divulgada como a de um monarca com um reinado conturbado, vida pessoal repleta de casos amorosos extraconjugais e responsável por deixar o país nas mãos de uma criança, ao partir para Portugal em batalha.

Dentre os esforços da ditadura militar brasileira em constituir tramas imagéticas que exaltassem a memória de heróis da história pátria, o ano de 1972 é significativo, devido aos festejos e às comemorações do Sesquicentenário da Independência. Os cerimoniais realizam-se durante o governo do General Emílio Garrastazu Médici (1969 1974) e são organizados por meio da composição de uma Comissão Executiva Central (CEC), com apoio de instituições de salvaguarda da memória nacional, a exemplo do IHGB. Adicionalmente, os festejos auferem visibilidade nacional, graças ao envolvimento da imprensa brasileira, sobretudo impressa, responsável por projetar uma memória dos heróis que se pretende eternizar por meio de comemorações e representações imagéticas.

Estas representações, “embora aspirem à universalidade de um diagnóstico fundado na razão, são sempre determinadas pelos interesses de grupos que as forjam" (CHARTIER, 1990, p.17) e são elementos propulsores de uma memória que se busca legitimar na dimensão imagética, seja em sua forma simbólica, ou alegórica e escrita, ou iconográfica. Neste sentido, evidencia-se um projeto de memorialização fomentado pela ditadura militar nos festejos do Sesquicentenário, por meio do investimento público nas imagens de heróis nacionais e figuras ilustres, configuradas pela narrativa sobre "um passado que se recusa a ser passado, segundo essas novas exigências, e sua recordação impõe-se como imperativo de ordem política" (GUIMARÃES, 2007, p.27). As imagens produzidas durante o Sesquicentenário recorrem a "uma linguagem, ao mesmo tempo ritualizada e simbólica, que se manifesta tanto no discurso como na representação iconográfica" (BATALHA, 1991, p.242) e enaltecem a liderança militar de D. Pedro I. A intenção era festejar os atributos do Imperador enquanto militar, por intermédio do culto à materialidade, mitificada e simbolizada pelo traslado dos restos mortais de Portugal ao Brasil, em abril de 1972. 
Este processo de reelaboração da imagem de D. Pedro I promovido pela ditadura militar mobilizou diversas linhas editoriais, responsáveis por disseminar as imagens vinculadas à personagem histórica e aos elementos capazes de garantir sua coerência. Sendo assim, o exercício de problematizar as imagens produzidas no período da ditadura militar recorreu à importância de pensar estas fontes bibliográficas e documentais, a partir de seus pressupostos editoriais, afinal a produção de livros, revistas, jornais e periódicos é pautada nas relações de dependência que envolvem diferentes atores, os quais são responsáveis por conferir "sentido aos textos que transmitem, imprimem e lêem" (CHARTIER, 2002, p.61). A significativa expressividade e a circulação nacional destas publicações impressas conferem visibilidade às representações imagéticas e à simbologia alegórica no regime militar, em vias de "lembrar para comemorar, documentar para bem festejar" (SCHWARCZ, 1993, p.108).

O mercado editorial das revistas se refestelava com a difusão das imagens dos heróis militares e, de uma maneira ou de outra, conferia visibilidade aos investimentos do governo autoritário nas formas de lembrar. Desta forma, compete destacar que as narrativas acerca do passado e a memória são campos permeados por interesses particulares, ou coletivos, sendo muitas vezes representativos de “disputas políticas, sociais e, sobretudo, de registros das práticas de exercício do poder" (DELGADO, 2010, p.126). Portanto, cabe enfatizar a expressividade das Revistas O Cruzeiro e Manchete no mercado editorial brasileiro no início da década de 1970, ambas componentes do corpus documental deste estudo, voltado à análise das representações imagéticas na mitificação de D. Pedro I como herói nacional, empreendida pelo governo militar.

\section{O Cruzeiro e a edição do "Brasil mais Brasil"}

A revista O Cruzeiro, fundada em 1928, integrava o grupo "Diários Associados", pertencente ao magnata das comunicações no Brasil, Assis Chateaubriand. Dentre os anos de 1930 a 1950, a publicação torna-se predominante no mercado editorial brasileiro e destaca-se pela ampla utilização de recursos imagéticos, até então meramente ilustrativos na imprensa nacional, desprovidos de conexão com o texto. Por conseguinte, 
a publicação torna-se pioneira na difusão do fotojornalismo no Brasil, inspirada no modelo de periódicos estrangeiros, a exemplo da revista francesa Paris Match e da norteamericana Life (SETEMY, 2008, p.91). Após os anos de 1950, a revista O Cruzeiro realiza frequentes ampliações em seu parque gráfico e atinge a tiragem impressionante de 720.000 exemplares em 1954, soma que demonstra a expressividade da publicação em território nacional. Mesmo diante do surgimento de uma publicação concorrente (Revista Manchete - 1952), O Cruzeiro mantêm-se como referência no campo editorial até meados dos anos de 1960 e inscreve em suas páginas "uma trama de imagens e ideias emblemáticas de um país que pretendia ser moderno e inovador" (GAVA, 2005, p.136). Este fenômeno editorial persiste até a segunda metade da década de 1970, quando a publicação sofre um decréscimo em suas vendas, dada as constantes mudanças do mercado brasileiro de revistas, bem como a própria diversificação das opções de leitura e segue até 1988, data do encerramento de suas atividades.

Durante os festejos do Sesquicentenário da Independência em 1972, a Revista O Cruzeiro foi responsável pela produção de uma edição comemorativa e "histórica", em 13 de setembro, intitulada "Brasil Mais Brasil”. Ao seguir os modelos que popularizaram a publicação no mercado editorial brasileiro, os editores utilizam amplamente recursos imagéticos que se encontram entrelaçados às narrativas inscritas em suas páginas. A publicidade constante nesta edição comemorativa, demonstra o seu envolvimento junto aos festejos do Sesquicentenário e evoca elementos do passado histórico em suas tramas imagéticas. Este recurso torna-se visível em uma imagem publicitária da empresa Varig, a qual, sob o fundo verde-amarelo da bandeira nacional, nomina uma lista de vultos ilustres da história pátria, que incluem D. Pedro I e o alferes Tiradentes. Na página dedicada à Companhia Brasileira de Energia Elétrica, o recurso imagético esforça-se em demonstrar que "não é o tempo que consolida a independência de um povo, mas sim a sua energia" (O CRUZEIRO, 13 set./1972, p. 242), enquanto na publicidade reservada à Companhia Siderúrgica Nacional, os dizeres publicitários avisam ao “Presidente Médici: o futuro chegou! Estamos aí" (O CRUZEIRO, 13 set/1972, p.243-244).

As páginas publicitárias da revista O Cruzeiro tornam-se espaços lucrativos, tanto para a revista, quanto para uma parcela do empresariado, que propaga suas homenagens 
aos festejos fomentados pelo governo autoritário. Por extensão, a revista produz discursos e imagens que realizam apologias à "materialidade dos novos tempos, apontando para um futuro calcado na ideia largamente difundida para a constituição da sociedade de informação" (SERPA, 2008, p.277). Estas projeções de renovação tecnológica e alforria econômica também se baseiam na representação de um passado capaz de conferir autenticidade à contemporaneidade ditatorial e, nestes termos, a edição do periódico apresenta artigos que reforçam elementos da história nacional, elencados sob o título “Ontem, o Brasil” (O CRUZEIRO, 13 set./1972, p.8-28). A imagem do imperador D. Pedro I, na abertura do artigo, torna-se paralela à fotografia do presidente Médici, personagem visto como representante das lideranças de "uma nação alegre, jovem e confiante", a qual "se apresta para a apoteose das comemorações dos cento e cinquenta anos de proclamação da sua autonomia política" (O CRUZEIRO, 13 set./1972, p.30). Destarte, o arsenal imagético presente na edição comemorativa e O Cruzeiro evidencia o fomento à vinculação entre o Imperador morto e o presidente militar empreendido pelo governo autoritário, no afã de ressignificar o passado, com vistas a cristalizar sua monumentalização física ou imagética na contemporaneidade ditatorial.

Este esforço múltiplo na atribuição de sentidos ao passado ainda conta, nas páginas da "edição histórica do Sesquicentenário", com o uso de fragmentos da memória, expressos por meios iconográficos. Desta forma, a difusão de quadros da história pátria nas páginas da revista $O$ Cruzeiro, com imagens que representam 0 Imperador D. Pedro I e momentos significativos do passado monárquico, a exemplo do grito do Ipiranga, representado na obra de Pedro Américo (1888), demonstra a utilização de "fragmentos do ritual já instalado - da ideologia significante - apoiando-se em 'retalhos' dele para instalar o novo" (ORLANDI, 1993, p.13). Denota-se o intento legitimador dos festejos do Sesquicentenário e da veiculação de imagens nesta conjuntura histórica, com a intenção de cristalizar um universo simbólico produzido pelos militares, a partir de elementos imagéticos preexistentes e devidamente ressignificados.

As tramas imagéticas em torno da figura do imperador adquirem um aspecto comemorativo, solene, pautado em elementos simbólicos carregados de significados quepersonificam o monarca e atribuem-lhe o papel de "fundador" da Pátria e representante dos "construtores da nacionalidade" (O CRUZEIRO, 13 set./1972, p.8). Os 
atos fundadores são, na perspectiva de Carlos Fico, um indício das fragilidades existentes na "liturgia do poder", e que, em vias de fortalecê-la, recorre a símbolos e mitos que referenciam os instantes fundacionais (FICO, 1997, p.54). Por conseguinte, a ampla divulgação articula-se ao intento do governo autoritário em institucionalizar o mito do “libertador" D. Pedro I e sacralizar o corpo do herói morto por meio dos cerimoniais inerentes ao traslado de seu esquife pelas capitais brasileiras, entre os meses de abril e setembro de 1972.

Na edição especial de O Cruzeiro, o destaque recai sobre o Brasil de "ontem", personificado na figura de D. Pedro I e, em seu arcabouço iconográfico, também fica evidenciado o Brasil de "hoje" (Figura 1), manifesto na imagem do presidente general, cujo discurso reforça as grandes obras de efeito desenvolvimentista em sua gestão, por ocasião das comemorações de seis anos do Golpe civil-militar de 1964, denominado pelos militares como "revolução", em abril de 1970.

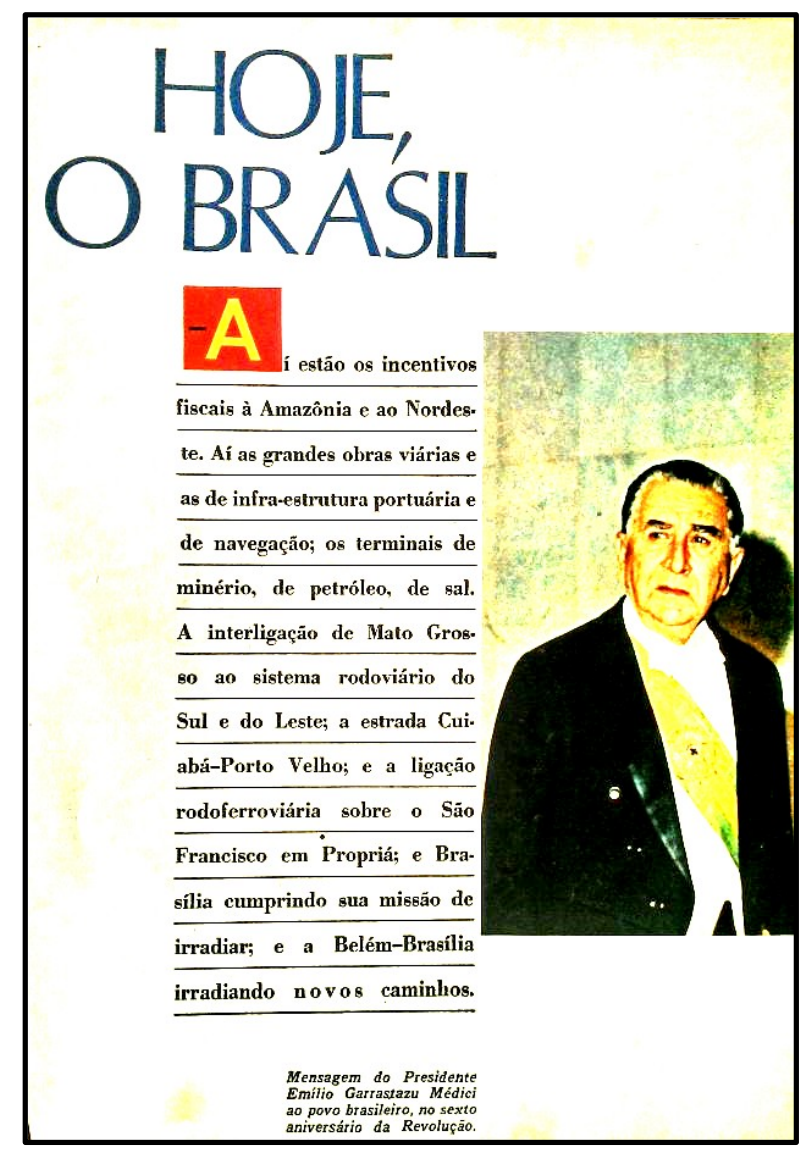

Figura 1. Mensagem do Presidente Médici quando o governo autoritário comemorou seis anos da chamada "revolução", no ano de 1970, recuperada para os festejos do Sesquicentenário da Independência. (O CRUZEIRO, 13 set./1972, p. 29). 
Os investimentos imagéticos, portanto, visam enraizar a memória em sua materialidade, ação que no Sesquicentenário da Independência é expressa em atos simbólicos e cerimoniais, na ritualística inerente aos monumentos dedicados ao herói morto, bem como na veiculação de imagens positivas dos protagonistas dos festejos, para os quais são atribuídos significados que evidenciam seu caráter heroico e militar. As narrativas imagéticas demonstram uma consciência de distanciamento em relação ao passado, cujo esfacelamento em resíduos desperta uma "curiosidade pelos lugares onde a memória se cristaliza (...)" (NORA, 1993, p.7) e permite a sua continuidade.

Esta difusão de imagens promove uma reelaboração em torno da figura de D. Pedro I e demonstra as tentativas dos mandatários da ditadura militar em eternizá-lo no panteão dos heróis nacionais durante os festejos do Sesquicentenário. A propagação das tramas imagéticas neste evento, no caso do periódico O Cruzeiro, torna-se inerente aos pressupostos editoriais da "edição histórica", amplamente ilustrada com representações iconográficas de um passado solene, devidamente ressignificado no escopo de garantir um clima de prosperidade econômica na contemporaneidade ditatorial. Neste processo, a ênfase da edição comemorativa da publicação recai sobre o suposto caráter desenvolvimentista fomentado pelo governo autoritário. Em consonância com esta proposta, o Brasil de "hoje" estaria representado pela figura do Presidente militar e, portanto, vinculado a um ideal de independência econômica, elemento amplamente enfatizado na "edição histórica do Sesquicentenário", por meio de representações imagéticas e textuais, sobretudo na composição de tramas publicitárias.

Os investimentos do governo autoritário nas formas de lembrar não se restringem apenas a esta edição intitulada "Brasil mais Brasil” e também são evidenciados em outra publicação presente nesta conjuntura histórica, a Revista Manchete, responsável pela formulação das tramas imagéticas dos festejos, com ênfase no traslado do esquife imperial. 
A Manchete, o tanque de guerra e o esquife com os restos mortais do "imortal"

A Revista Manchete inicia suas atividades junto ao mercado editorial brasileiro em abril de 1952. Trata-se de um periódico semanal, principal publicação da Editora Bloch, conglomerado editorial sob a direção de Adolpho Bloch que, em meados da década de 1970, constitui-se como forte concorrente da revista O Cruzeiro. Com ênfase nos seus recursos imagéticos, a fórmula jornalística da Revista Manchete baseia-se em apresentar, ao longo de suas páginas, "vinte por cento de texto, trinta por cento de títulos e espaços em branco e cinquenta por cento de fotografia, além dos crescentes investimentos em equipamentos gráficos (...)" (SETEMY, 2008, p. 92). Também demonstra ser uma publicação alinhada com o governo militar, agindo como um órgão difusor de suas ações propagandísticas nos anos de 1970 (SETEMY, 2008, p. 93), experiência evidenciada nas edições da revista dedicadas ao Sesquicentenário.

Em suas edições de abril, maio e setembro de 1972, a revista difunde tramas imagéticas que referenciam o universo simbólico em torno da figura de D. Pedro I. Nestes termos, a publicação promove imagens dos cerimoniais que referenciam o traslado de Portugal para o Brasil do esquife imperial, e reforçam a frequente associação do monarca a elementos de cunho militar. A composição da figura de D. Pedro I como herói envolve elementos de um passado que reforça sentimentos patrióticos, daí o apelo as suas características como homem das armas e mito fundador do ideal de Nação propagado no século XIX. Para levar adiante este desafio, o evento comemorativo retratado nas fotografias da Manchete reforçam o caráter militar associado ao traslado, pois durante os desfiles do Sesquicentenário, o esquife do Imperador foi transportado sobre um tanque de guerra, ladeado pelos “Dragões da Independência”, membros da guarda presidencial (Figura 2). 


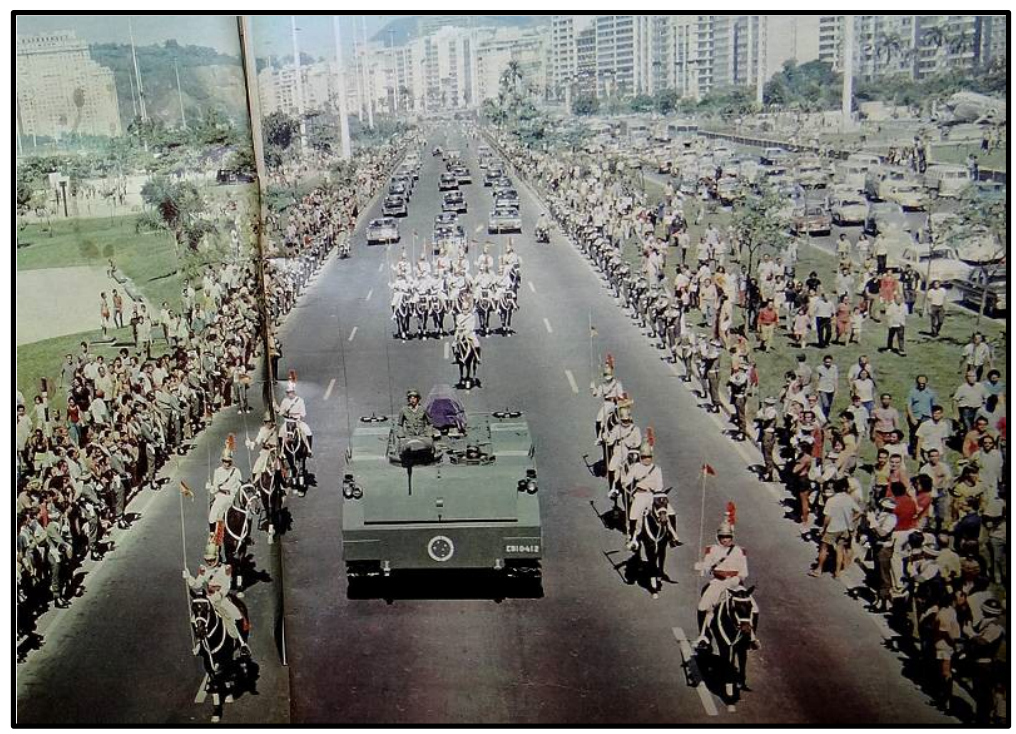

Figura 2. O corpo do imperador morto é transportado sobre um tanque de guerra, ao longo do Parque do Flamengo, no Rio de Janeiro em 1972. (MANCHETE, 6 maio/ 1972, p.7).

A constituição do evento fomenta uma ressignificação de elementos da história pátria, executada após um acordo diplomático luso-brasileiro que promove o retorno ao Brasil de parte dos restos mortais do "imortal” D. Pedro I, com exceção do coração, deixado por ele em testamento à cidade do Porto. O esquife do primeiro imperador é transportado por uma comitiva liderada pelo presidente português, Almirante Américo Tomás, e chega ao Brasil em 22 de abril de 1972, momento significativo, pois sugere uma associação aos projetos de comemoração do assim chamado "protomártir" da Independência, a saber, Tiradentes, em 21 de abril. Esta tentativa de articular as personagens de D. Pedro I e Tiradentes evidencia os usos de fragmentos da história por parte do governo militar, em vias de associar a imagem do líder monárquico, símbolo nacional, com o alferes inconfidente, figura central no panteão de heróis instituído pelo regime republicano no Brasil (CARVALHO, 1993, p.55).

Nesta conjuntura, os restos mortais do Imperador são transportados pelas capitais brasileiras, a partir de 25 de abril, para demonstrar o caráter presencial que o projeto apresentava frente à constituição mitológica do herói. A ritualística que cerca o traslado dos despojos de personagens considerados ilustres vincula-se aos usos da memória e é 
praticada e discutida no Brasil desde a década de 1920, sobretudo nas comemorações do centenário da Independência brasileira (1922) e do nascimento de D. Pedro II (1925). Entretanto, a estratégia do regime militar em conduzir o primeiro Imperador à virtude e mitificá-lo junto ao panteão dos heróis nacionais promove uma reelaboração de elementos simbólicos no afã de vincular sua personagem a um ideal de líder militar, representante da "unificação do país" e "fundador do Império brasileiro". Por meio das tramas imagéticas constituídas no evento e difundidas nas revistas Manchete e $O$ Cruzeiro, as representações simbólicas do herói morto e de seus feitos em vida esforçam-se em sugerir uma continuidade na liderança militar, para interrelacionar D. Pedro I com o presidente Médici. Os ritos e os símbolos representados são significativos deste intento, a exemplo do logotipo do Sesquicentenário, criado por Aloísio Magalhães, que apresentava, em forma de vinheta, as datas interligadas de 1822 e 1972, ou por meio de elementos materiais: cunhagem de moedas (Figura 3) e medalhas comemorativas, as quais associam a efígie do presidente militar à do "imortal” Imperador, com o objetivo de perpetuar os vínculos entre os homens das armas.

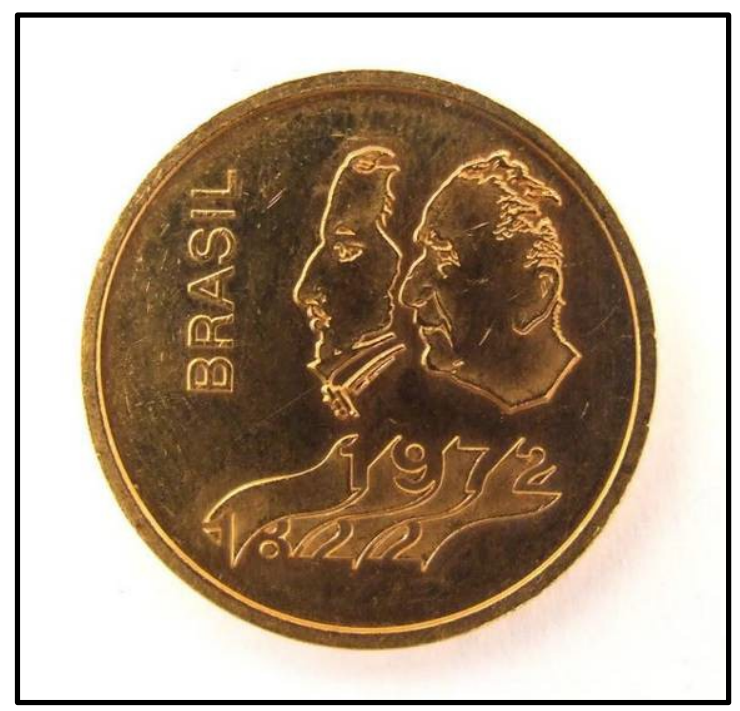

Figura 3. A difusão de moedas comemorativas, pela ocasião do Sesquicentenário da Independência, vincula a efígie de D. Pedro I ao Presidente General Médici. (Disponível em: <http://www.bcb.gov.br/?MOCRUZA70> Acesso em: 25 ago. 2012)

Tal simbologia da moeda está relacionada ao processo de "reinvenção do otimismo" (FICO, 1997, p. 64) que, em termos de propaganda política, juntamente com o traslado dos restos mortais, remete a uma tentativa da ditadura em 'santificar' o corpo do 
herói morto, personagem que já integrava o panteão dos grandes vultos nacionais. A estratégia do regime ditatorial em reelaborar a imagem de D. Pedro I está relacionada às suas façanhas militares realizadas no comando do exército português, a partir de 1828, quando lutou contra o governo absolutista de seu irmão, D. Miguel. Deste modo, a representação imagética do traslado ao Brasil de seus restos mortais, em abril de 1972, no governo do General Médici, demonstra a simbologia constitutiva dos "lugares de memória" (NORA, 1993), muito expressiva junto às políticas de Estado autoritário, sedentas por atos comemorativos envoltos em cerimoniais capazes de mobilizar capitais estratégicas e, por conseguinte, legitimada por intermédio da peregrinação pelo território nacional do corpo imperial como representação simbólica do herói morto.

Os lugares de memória vinculam-se a um "momento de articulação [em que a] consciência da ruptura com o passado se confunde com o sentimento de uma memória esfacelada, [tendo em vista que] o esfacelamento desperta ainda memória suficiente para que se possa colocar o problema de sua encarnação" (NORA, 1993, p.7). As tramas imagéticas constitutivas das simbologias inerentes aos lugares de memória demonstram os usos do passado empreendidos pelo governo militar, com a finalidade de sugerir um senso de continuidade, por meio do qual o passado encontra-se fragmentado, residual, e precisa ser salvo para servir o presente e o futuro (LE GOFF, 1990, p.247). A reelaboração positiva em torno da imagem do imperador D. Pedro I evidencia os apelos em constituir lugares depositários de um passado heroico, celebrado por meio de festejos eivados de um caráter espetacular. Estas ações possuem o fito de marcar a lembrança e institucionalizar mitos, a partir das representações imagéticas simbolizadas pela figura do Imperador como ente personalizante de um passado coeso e legítimo, destituído de quaisquer máculas ou equívocos.

As fotografias veiculadas pela Manchete recebem destaque e são cuidadosamente selecionadas na edição, marcadas pela presença predominante de personagens oriundas dos meios militares, homens das armas com suas fardas, situação que cerca os cerimoniais do Sesquicentenário e envolvem o cortejo do corpo imperial em um tom de solenidade. A população, mesmo presente nas fotografias, fica apartada do desfile, diante da presença de militares que ladeiam o cortejo em um ato simbólico, vinculado à intencionalidade de 
sacralização do corpo do herói morto, com o propósito de instaurar "a lembrança no sagrado" (NORA, 1993, p.9) e mitificar a personagem do Imperador.

Em outra fotografia, o esquife imperial é retirado pelos "Dragões da Independência" (Figura 4) e os despojos de D. Pedro I são entregues pelo presidente português, Almirante Américo Tomás, ao presidente brasileiro, General Médici. Este ato simbólico foi realizado no monumento dedicado aos mortos da Segunda Guerra Mundial, enquanto aviões da Força Aérea Brasileira realizavam suas acrobacias para marcar o espetáculo.

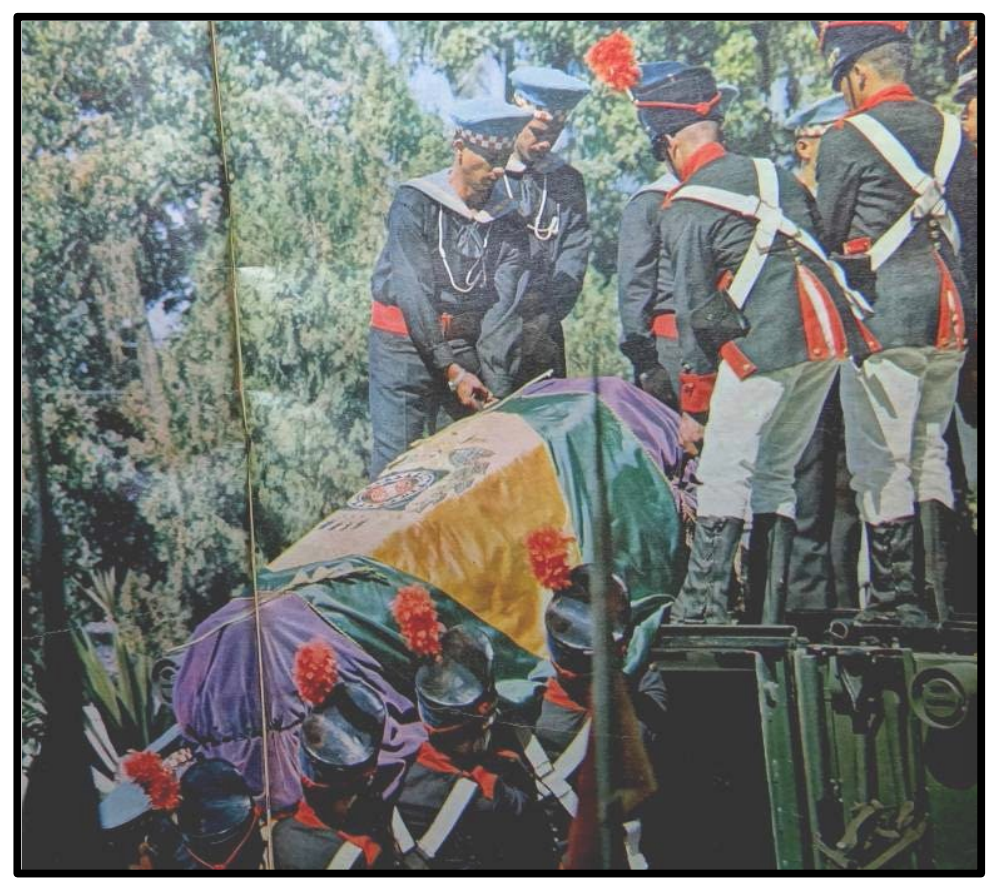

Figura 4: Sobre ombros e mãos militares, o esquife do "libertador" é levado do Monumento aos Mortos da Segunda Guerra Mundial ao Museu Nacional. Rio de Janeiro, Abril de 1972.

(MANCHETE, 6 maio/1972, p.12-13)

O estratagema articula um passado heroico, representado na materialidade simbólica dos restos mortais do "libertador" do Brasil, alicerçado a um monumento em homenagem aos homens das armas, configurado como "lugar de memória", mediante confirmação das lideranças políticas oriundas dos meios militares.

Adicionalmente, o evento se insere no campo da política externa brasileira do início da década de 1970, que busca aproximar-se de outros países, sobretudo com o intuito de fortalecer a diplomacia luso-brasileira (FICO, 1997, p.64), que também se encontrava sob um regime político autoritário. A dimensão militar das comemorações simbolizada pela 
figura heroica torna-se evidente, assim como os esforços em monumentalizar a personagem de D. Pedro I pelo mecanismo das tramas imagéticas marcadas pela memória.

As fotografias difundidas nas edições da Revista Manchete referenciam os desfiles cívicos nos quais o féretro imperial circula, inicialmente no Rio de Janeiro e em Porto Alegre. As imagens de desfiles cívicos ofertam aos pesquisadores uma oportunidade ímpar para relacionar elementos do passado e da memória, que se pretende perpetuar, assim como as tentativas de constituição de novos sentidos por meio do ritual simbólico. Capazes de mobilizar a participação de centenas ou milhares de pessoas, os desfiles são fomentados por grupos distintos que operam no interior das possibilidades políticas de seus tempos, os quais, nas representações imagéticas do Sesquicentenário da Independência, visam compor significados, a partir da afirmação constante de D. Pedro I como símbolo nacional e líder militar. Por extensão, a ritualística que cerca os desfiles cívicos recorre a "uma força emocional e uma expressividade estética que faltava à mera formulação literária de ideias, ou valores" (RYAN, 1992, p.179), potencial explorado pelo governo militar com a finalidade de sacralizar o corpo do imperador morto e institucionalizar o mito do herói.

A valorização dos elementos simbólicos de caráter militar nas imagens demonstra que o esquife é inicialmente conduzido por marinheiros portugueses e, posteriormente, pelos oficiais da Marinha brasileira. A ritualística inerente ao arsenal imagético do traslado também se faz presente pela via textual e reforça que o monarca retorna de Portugal "para ficar conosco para sempre", recepcionado no Brasil "sob grande emoção popular" (MANCHETE, 6 maio/1972, p.5-6), momento simbólico que marca o regresso definitivo do “imortal” ao Brasil, entregue por mãos militares. As solenidades que envolvem o traslado em elementos simbólicos continuam após os discursos oficiais de Médici e Américo Tomás, instante em que "ao som do Hino da Independência, cantado por colegiais, quatro soldados dos Dragões da Independência colocaram uma grande bandeira brasileira sobre o esquife" (MANCHETE, 6 maio/1972, p.5-6).

Em Porto Alegre, cidade em que se inicia a peregrinação dos restos mortais em 25 
de Abril, o cortejo mobiliza um desfile no qual o caixão é ladeado por uma comitiva militar e está transportado sobre uma carruagem fúnebre (Figura 5), elemento que enfatiza o aspecto solene, ainda que sombrio, que cerca as tramas imagéticas de parte das comemorações do Sesquicentenário. A escolha de Porto Alegre como local para início dos desfiles, não foi casual e insere-se na função simbólica de rememorar um elemento da história militar, a saber, o envolvimento do imperador com a campanha na Província Cisplatina, em 1826, em referência à sua atuação na marcação territorial brasileira na região sul.

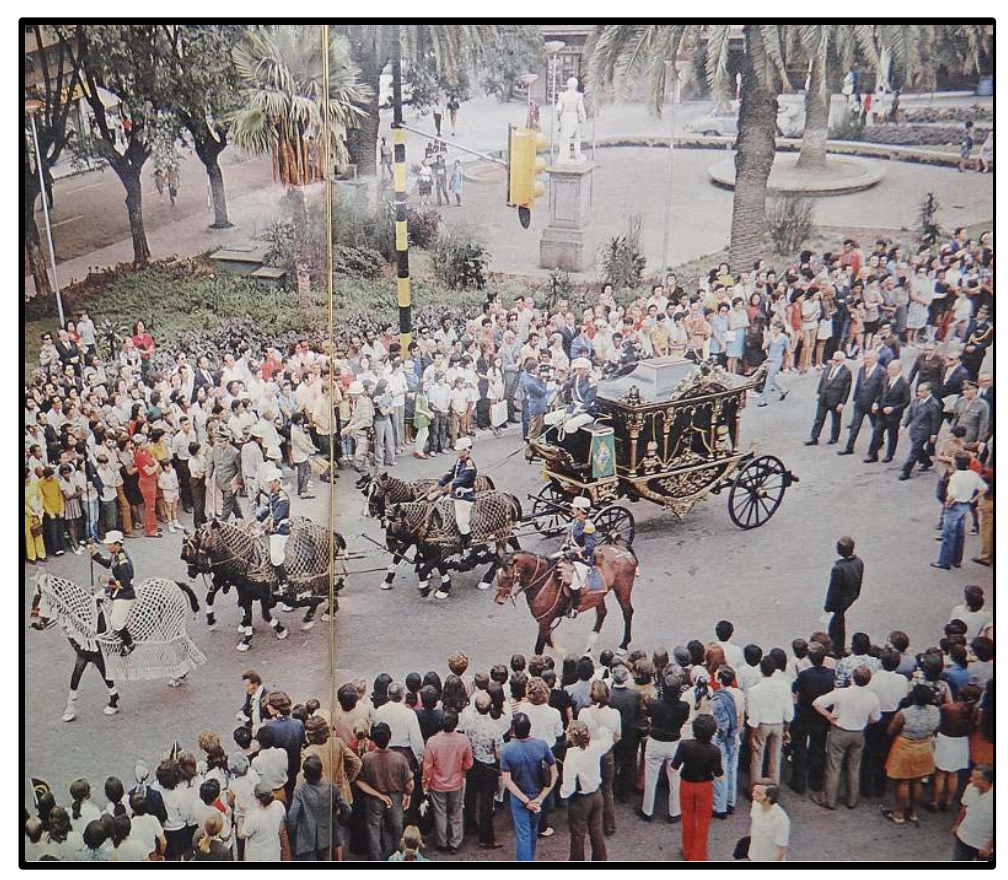

Figura 5: O esquife chega a Porto Alegre na peregrinação dos restos mortais de D. Pedro I, em 25 de abril de 1972. (MANCHETE, 13 mai. 1972, p.16-17)

As fotografias do traslado e das comemorações do Sesquicentenário que acompanham as edições da Manchete também contam com a presença de retratos personalizados do Imperador, a exemplo do artigo "Porque o coração do imperador ficou no Porto?". Em oposição aos retratos de D. Pedro I e seu irmão, aparece a figura de D. Miguel "o absolutista, usurpador do trono", acompanhado de uma narrativa interessada em marcar que "depois de abdicar no Brasil, D. Pedro lutou para levar ao trono português uma princesa brasileira" (MANCHETE, 29 abr./1972), em referência à filha do Imperador, D. Maria II. Desta forma, o vínculo entre a narrativa iconográfica do passado monárquico e da 
contemporaneidade ditatorial baseia-se nos "retalhos" (ORLANDI, 1993, p.13) de uma simbologia imagética já instalada, em vias de sustentar a construção de uma nova memória manifesta no vulto ilustre, o qual se torna depositário de um passado militar e sustentáculo das ações do governo autoritário: comemorar para bem perpetuar.

Este passado é materializado nas representações de monumentos vinculados à história pátria e à Independência, a exemplo do Monumento do Ipiranga, em São Paulo. A estátua equestre de D. Pedro I figura de modo expressivo nas imagens do Sesquicentenário e, além de simbólica, cumpre uma função narrativa, pois se refere ao momento preciso do grito da Independência. Em seu aspecto memorativo, "o monarca é fixado para a eternidade no momento em que proclama o nascimento do Brasil e garante sua unidade" (ENDERS, 2000, p. 57). As imagens das estátuas equestres do imperador apontam os investimentos da política autoritária na cristalização da memória em vias de “evocar o passado e perpetuar a recordação" (LE GOFF, 1990, p.536) por meio das tramas imagéticas. O intento do governo militar em construir um aspecto solene e heroico em torno do Imperador é ilustrado nos símbolos e nos monumentos produzidos nesta conjuntura histórica e representado nas edições da Revista Manchete (Figura 6).

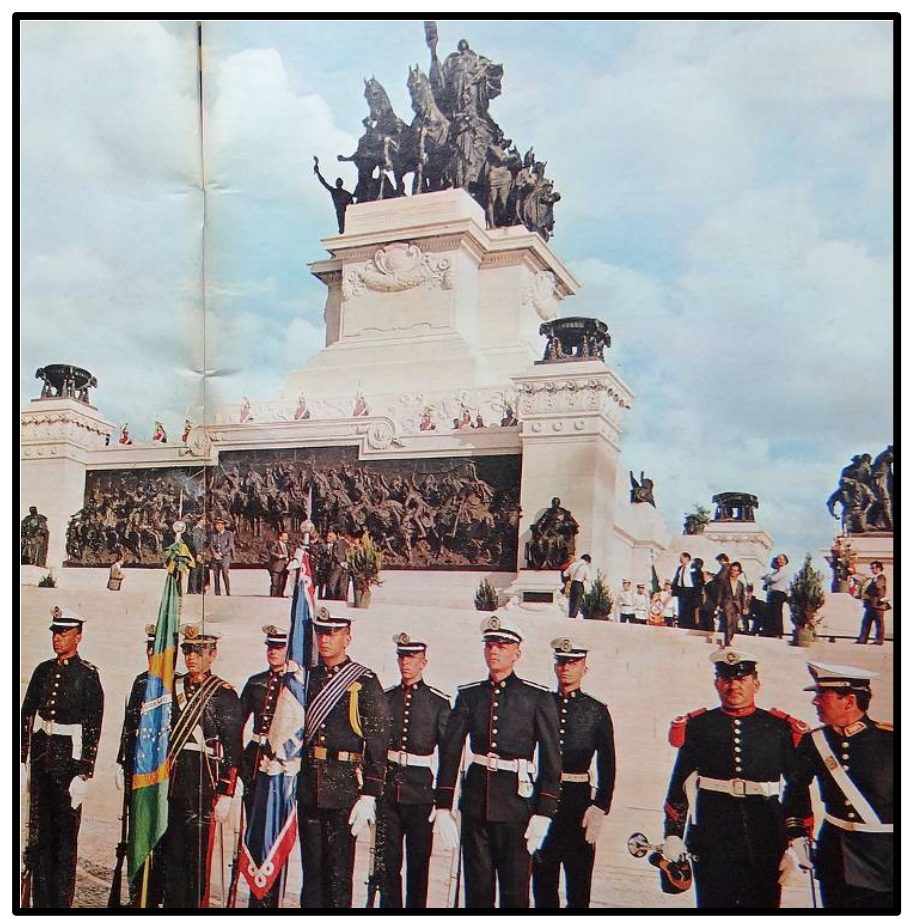

Figura 6. As solenidades do Sesquicentenário da Independência, no Monumento do Ipiranga, em São Paulo, demonstram a ênfase nos elementos militares (MANCHETE, 13 maio/1972, p. 6-7). 
Para além das representações imagéticas, denota-se uma intensa articulação com diversas formas de expressão. Neste sentido e, em particular nos períodos de repressão e autoritarismos, ocorre uma espécie de imbricação entre política-imagem-imprensa, que constitui precioso filão para a pesquisa histórica e para a análise da memória política, em vias de "identificar as representações de legitimação e reforço da autoridade" (PACHECO, 2008, p.174). No interior deste processo que relaciona o ideal de um passado heroico e os usos das imagens na composição das tramas do presente, surgem os elementos de suporte para o intento dos militares na constituição de significados capazes de marcar memórias individuais, ou coletivas acerca dos eventos registrados.

As imagens fomentadas revelam tramas que estabelecem um diálogo com o passado, mediado por representações imagéticas que evocam um tempo heroico, propulsor de aspectos da memória. A memória opera por caminhos vulneráveis e está sujeita às manipulações, portanto, se "alimenta de lembranças vagas, telescópicas, globais ou flutuantes, particulares ou simbólicas, sensível a todas as transferências, cenas, censura ou projeções" (NORA, 1993, p.9). As imagens de heróis produzidas neste período evidenciam os usos das formas de lembrar no projeto de constituição do mito do "libertador", configurado na constante ênfase de elementos da história pátria difundidos nas linhas editoriais. Considerando-se a sua ampla difusão, estas representações imagéticas ofertam suporte aos discursos oficiais em seu escopo de tentar impor uma determinada "concepção do mundo social, os valores que são os seus, e o seu domínio" (CHARTIER, 1990, p.17), elementos que permitiriam marcar a memória e monumentalizar o mito do monarca heroico.

As representações imagéticas veiculadas por estas publicações demonstram a apropriação de elementos significativos e a incorporação de aspectos simbólicos de cunho militar, responsáveis por configurar na memória fragmentos da história pátria. Neste caso, o “libertador” D. Pedro I torna-se não apenas o responsável pela Independência brasileira, mas sim a personificação da união entre as duas pátrias, Portugal e Brasil, ambos sob regimes autoritários durante a década de 1970, conforme mencionado anteriormente. Desta forma, nas páginas da revista, os cerimoniais do traslado são marcados pela "união no Ipiranga" de Portugal e Brasil (Figura 7). 


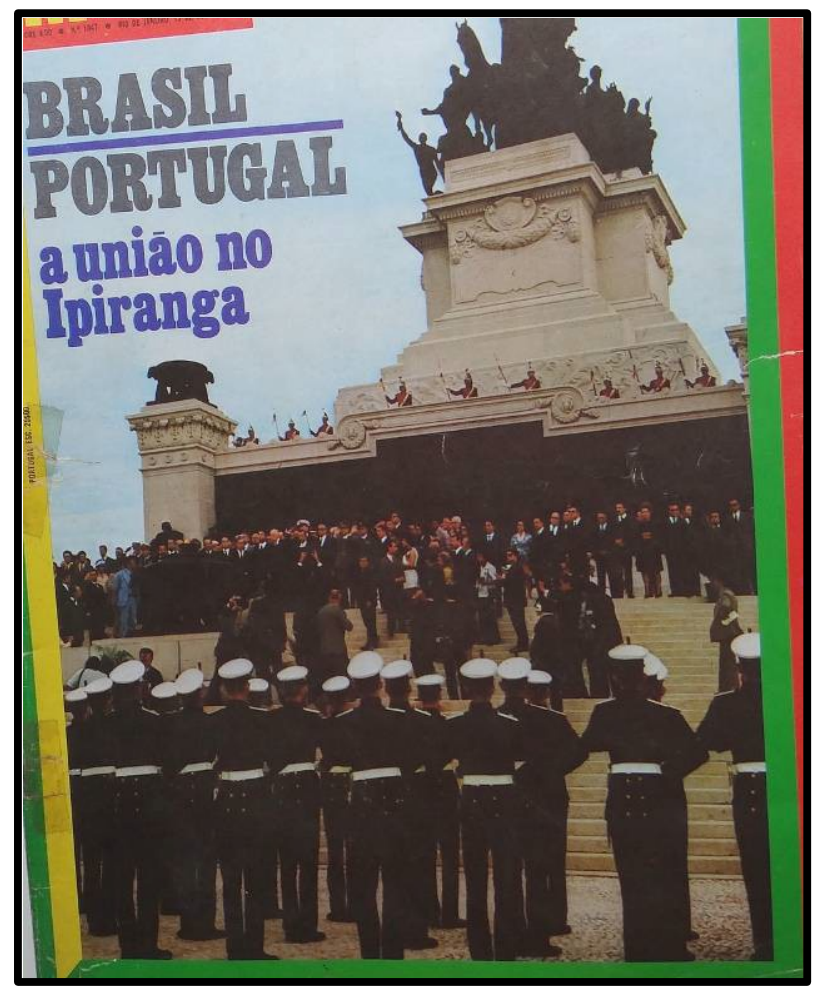

Figura 7. As representações imagéticas do Sesquicentenário referem-se a D. Pedro I como o catalisador da "união" de Brasil e Portugal. (MANCHETE, 13 maio/1972).

As fotografias da chegada dos restos mortais evidenciam a forte presença de figuras militares, personagens em fardas que, "a passos lentos e cadenciados, levaram o esquife contendo os restos mortais de D. Pedro I até um tablado amarelo-ouro, no centro do Pátio do Monumento dos Pracinhas" (MANCHETE, 6 maio/1972, p.4-5). A associação entre estes elementos simbólicos e monumentos militares demonstra que a representação imagética do translado promove uma afirmação constante do caráter solene e militar dos eventos. Além disso, a estatuária monumental presente no Sesquicentenário da Independência, é um elemento importante na constituição dos lugares de memória, produzidos a partir do "sentimento que não há memória espontânea" (NORA, 1993, p.13) e de que, com o fito de sua preservação, requer comemorações, elogios fúnebres, celebrações e, a partir destes, visibilidade garantida pela difusão das suas imagens em publicações.

As imagens expressam a intensa participação da marinha portuguesa e de oficiais 
brasileiros nos rituais que cercam as comemorações. Cabe destaque à fotografia que ilustra a coroa do "libertador", transportada em mãos militares, elemento simbólico da “realeza de D. Pedro I" (MANCHETE, 6 maio/1972, p.10) e representativo legitimador de sua autoridade como monarca brasileiro (Figura 8).

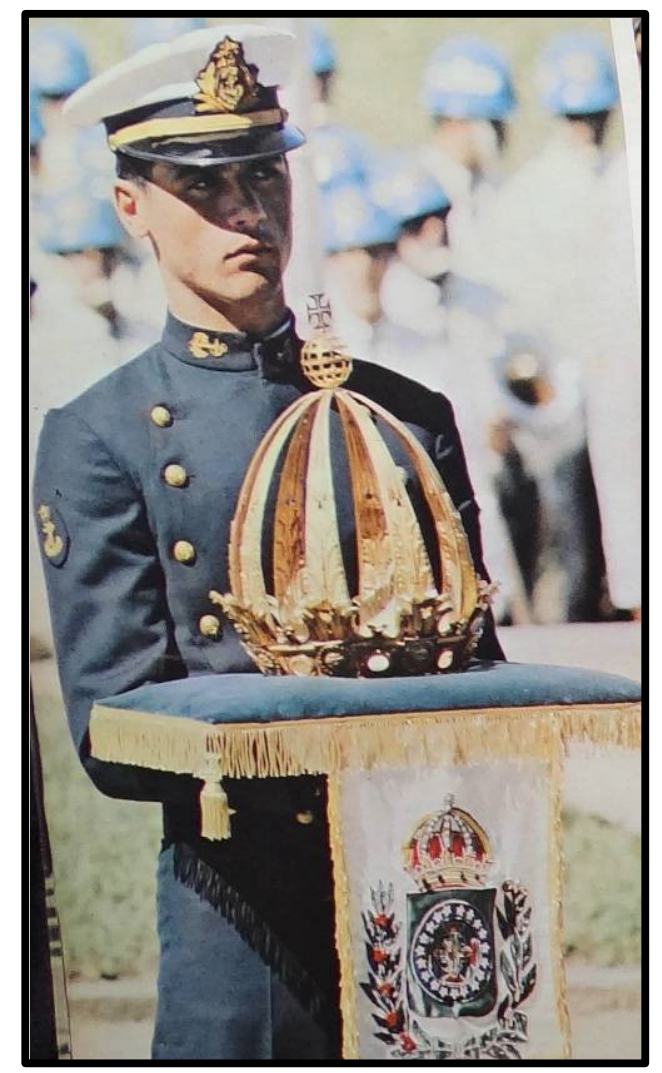

Figura 8: Nas mãos de um membro do corpo de fuzileiros navais, a coroa imperial é representativa da realeza de D. Pedro I. (MANCHETE, 6 maio/1972, p.10).

O cerimonial promove a identificação de D. Pedro I como imagem de personificação do mito do "imortal”, responsável pela independência e, paradoxalmente, pela reunificação simbólica dos dois países. As fotografias não têm existência desprovida de autoria, portanto, resultam de um processo de criação por parte dos fotógrafos, o qual é construído a partir de códigos simbólicos (KOSSOY, 2007, p.42) expressos em imagens que demonstram o retorno dos restos mortais do imortal, entregues por lideranças militares e autoritárias. Some-se a isso, o reforço e evidência na materialização dos discursos oficiais em um evento de particular importância para a reconfiguração da memória do "libertador". Esta memória se perpetua pela sagrada lembrança e se sustenta 
em um arsenal concreto, na materialidade dos monumentos ou nas tramas imagéticas, responsáveis por produzir novos sentidos regidos pelo universo simbólico inerente às representações.

Após o cerimonial nos lugares de memória no Rio de Janeiro, o esquife imperial foi conduzido em direção ao Museu Nacional, antiga residência Imperial, na Quinta da Boa Vista, onde estavam os descendentes diretos da Família Real Portuguesa como representantes autênticos do passado revivido. Isto indica que outras personagens também estiveram envolvidas nos festejos do Sesquicentenário, tanto os descendentes do Imperador quanto personalidades eclesiásticas. A presença destas figuras está aliada à adesão do empresariado brasileiro aos eventos do Sesquicentenário, expressa por meio da publicidade veiculada na "edição da Independência" da Revista Manchete ou da “edição histórica do Sesquicentenário” da Revista O Cruzeiro.

A associação de personalidades civis, militares e eclesiásticas em um evento promovido pela ditadura converge para as interpretações historiográficas que, ao final dos anos de 1970 e ao longo da década de 1980, tendem a visualizar o golpe civil-militar de 1964 e o estabelecimento do governo autoritário como resultante de forças conspiratórias oriundas de diversos grupos, organizações e instituições, e que contam com o apoio de jornais de circulação nacional (DELGADO, 2010, p.142). Estas interpretações enfatizam a participação do empresariado nacional, de membros do clero, de partidos políticos opositores ao governo dito populista e do Departamento de Estado norte-americano na desestabilização da administração de João Goulart e no estabelecimento do governo militar.

O término do governo de João Goulart (1961-1964) e o golpe que leva ao estabelecimento da ditadura militar no Brasil em 1964 estão associados a inúmeros fatores políticos, sociais e econômicos (FERREIRA, 2003, p.346). A posição moderada de Jango gera a insatisfação de grupos conservadores, os quais se unem em uma força desestabilizadora que leva ao golpe, (DELGADO, 2010, p. 28) à extinção de partidos trabalhistas, à cassação de vários mandatos, repressão ao movimento sindical, prisões e encarceramento das liberdades básicas (FERREIRA, 2003, p.400). As ações do governo 
autoritário mobilizam-se em justificar a presença de um regime militar no Brasil diante da acusação, ou contestação de uma crise moral que supostamente se abate sobre o país (FICO, 1997, p.43). Além disso, visam evocar o início de um regime político posto como desvinculado das formas de governo entendidas como populistas, e que, “devidamente demonizadas, deveriam ser negadas, vencidas e varridas dos anais da história do país" (REIS FILHO, 2001, p. 347).

Por isso, as imagens que o governo militar buscou eternizar em sua incursão pelo passado, têm o claro objetivo de identificação com certos personagens da História do Brasil, mitificados por meio de datas comemorativas e eventos cívicos. Desta forma, as leituras do passado empreendidas pelo governo autoritário, expressas por meio das representações imagéticas do Sesquicentenário, apontam os intentos legitimadores que associam símbolos e alegorias de forte caráter militar às operações de memória que se constituem no evento. Destarte, o retorno dos restos mortais do "libertador" evoca uma continuidade que vincula desde "Pedro Álvares Cabral a Américo Tomás, passando por Pedro I" (MANCHETE, 6 maio/1972, p.16), ou mesmo uma história pátria de realizações ilustres “de Pedro I a Médici” (MANCHETE, 7 set./1972, p.26), assertivas que demonstram as múltiplas tentativas de justificar o governo militar com o apoio de elementos históricos.

As edições destas publicações no Sesquicentenário, em encartes especiais inteiramente coloridos, elencam aspectos da história do Brasil de "ontem" (O CRUZEIRO, 13 set./1972, p.8), cujos vultos ilustres tornam-se representativos da construção do ideal de nacionalidade. Com a finalidade de complementar o universo simbólico vinculado aos festejos de 1972, as edições das revistas Manchete e O Cruzeiro agregam textos de caráter histórico, a exemplo da missiva escrita por D. Pedro I, na qual alega ser sua vontade deixar seu “coração à heroica Cidade do Porto, teatro da minha verdadeira glória” (MANCHETE, 6 maio/1972, p.21). A vontade testamental do Imperador regeu parte dos projetos do traslado, tendo em vista que seu coração foi deixado na cidade do Porto, cuja "função simbólica" vincula o monarca à sua campanha militar contra o governo absolutista de D. Miguel. 
A institucionalização de D. Pedro I como uma figura heroica demonstra o intento ditatorial em promover "um passado inequívoco" por meio de uma "memória temporalizada, que se apresenta como institucional e legítima" (ORLANDI, 1993, p.12). Os processos de legitimação de um passado pátrio e memorável, sobretudo em conjunturas que referenciam mudanças de regimes políticos, frequentemente recorrem aos mitos de origem personificados em seus heróis, "símbolos poderosos, encarnações de ideias e aspirações, pontos de referência, fulcros de identificação coletiva" (CARVALHO, 1993, p.55). Desta forma, as representações imagéticas destes heróis nacionais, por meio do mercado editorial, dos meios de comunicação e das produções artísticas, promovem "batalhas de memória" (POLLAK, 1989), nas quais grupos diversos digladiam-se no afã de impor uma memória oficial e, no caso dos eventos que cercam o Sesquicentenário da Independência, com a intenção de promover o “imortal” Imperador ao panteão de vultos ilustres da história pátria.

\section{Considerações finais}

Os esforços empreendidos pelo governo autoritário cercam a reelaboração de imagens positivas em torno de figuras ilustres, representativas de um passado sugestivo de uma continuidade de lideranças militares. Nas comemorações do Sesquicentenário da Independência, em 1972, os usos da memória e de aspectos da história pátria ficam evidenciados por meio da personificação da figura do Imperador D. Pedro I, personagem até então vinculado a um reinado conturbado, vida pessoal repleta de casos extraconjugais que, ao abandonar o Brasil para recuperar o trono português, deixa a monarquia nas mãos de uma criança. A Comissão Executiva Central (CEC) do Sesquicentenário promove o retorno de parte dos restos mortais do Imperador em abril de 1972, com o propósito de comemorar para perpetuar a imortalidade do herói. O evento foi realizado após um acordo diplomático luso-brasileiro, seguido da peregrinação do féretro do monarca pelas principais capitais brasileiras.

A participação de instituições de salvaguarda da memória nacional, a exemplo do Instituto Histórico e Geográfico Brasileiro (IHGB), evidencia que os festejos do Sesquicentenário crescem em importância dentre os esforços de visibilidade do regime 
militar. Nesta conjuntura histórica, as imagens do Imperador em seu esquife são difundidas em periódicos de expressiva circulação, a exemplo das revistas Manchete e 0 Cruzeiro, responsáveis por edições especiais, publicadas na ocasião dos festejos, amplamente ilustradas, que se constituem como fontes documentais para análise e questionamentos acerca deste período da História do Brasil.

Nas páginas destes periódicos, o traslado dos restos mortais esteve envolto em uma simbologia alegórica que frequentemente associou o Imperador morto a elementos militares e ao próprio presidente General Médici, de modo a sugerir uma continuidade de lideranças militares. Isto porque a estratégia do regime militar brasileiro em conduzir D. Pedro I à virtude, por meio da reelaboração positiva de sua figura, está relacionada às suas façanhas militares.

Nas representações referenciadas em meio às imagens das solenidades dos festejos e de desfiles cívicos, o féretro imperial é transportado sobre um tanque de guerra e ladeado pelos “Dragões da Independência”, membros da guarda presidencial. Adicionalmente, a peregrinação do esquife iniciou-se em Porto Alegre, escolha que se articula à função simbólica de rememorar um elemento da história militar, a saber, o envolvimento do imperador com a campanha na Província Cisplatina, em 1826, para salvaguardar a fronteira sul do país.

Estes estratagemas são indicativos dos intentos ditatoriais em expor à população brasileira a imagem de um herói devidamente ressignificado e associado a um universo simbólico de forte caráter militar. A produção de imagens, emblemas e efígies que aproximam a figura de D. Pedro I com a do Presidente Médici, a exemplo das moedas comemorativas que circulam a partir de 1972, exemplificam os laços entre o presente e o passado constituídos a partir de uma memória oficial, cristalizada em torno de mitos, ritos e símbolos que envolvem o Sesquicentenário da Independência. A institucionalização do mito do "libertador" D. Pedro I e a sacralização de seu corpo, mediante traslado por algumas capitais brasileiras, demonstram o intuito de difundir entre a população sentimentos de amor, tanto à pátria, quanto aos heróis eleitos pelo governo autoritário vigente neste período histórico. 
As representações imagéticas analisadas evidenciam a simbologia dos elementos de memória evocados pela política do Estado autoritário, sedenta por atos comemorativos e envolta em cerimoniais de cunho espetacular. A ampla divulgação veiculada pelas revistas não demonstra uma clara vinculação entre os editores e os militares na utilização de aspectos da história pátria como arsenal imagético. Porém, as publicações nas revistas Manchete e O Cruzeiro, agregam visibilidade às intenções dos militares em apropriar-se de atos comemorativos simbólicos, efetivados pela "maquinaria" festiva dos cento e cinquenta anos da Independência do Brasil. Esta intencionalidade foi levada a cabo por meio da efetivação e organização do retorno dos restos mortais do "imortal" D. Pedro I ao território brasileiro, para mitificar sua representatividade como herói militar e autêntico representante da História nacional.

\section{Referências}

BATALHA, Cláudio Henrique de Moraes. Nós, filhos da revolução francesa: a imagem da revolução no movimento operário brasileiro no início do século XX. Revista Brasileira de História, v. 10, n. 20, p. 233-249, mar-ago de 1991.

BITTENCOURT, Circe. As tradições nacionais e o ritual das festas cívicas. In: PINSKY, Jaime. O ensino de história e a criação do fato. São Paulo: Contexto, 1988.

CARVALHO, José Murilo. A formação das almas: o imaginário da República no Brasil. São Paulo: Companhia das Letras, 1993.

CASTRO, Celso. Entre Caxias e Osório: a Criação do Culto ao Patrono do Exército Brasileiro. Revista Estudos Históricos. v.14, n.25, p.103-117, 2000.

CERTEAU, Michel de. A escrita da história. Rio de Janeiro: Forense Universitária, 1982.

CHARTIER, Roger. A História cultural: entre práticas e representações. RJ: Bertrand, 1990.

CHARTIER, Roger. Imagens. In: BURGUIÈRE, André (Org.). Dicionário das ciências históricas. Rio de Janeiro: Imago, 1993.

CHARTIER, Roger. Os desafios da escrita. São Paulo: UNESP, 2002. 
CHARTIER, Roger. Prólogo. In: . Cultura escrita, literatura e história. Porto Alegre: Artmed, 2001, p. XIII.

DELGADO, Lucilia de Almeida Neves. O Governo João Goulart e o golpe de 1964: memória, história e historiografia. Tempo, Niterói, v. 28, p.123-143, 2010.

ENDERS, Armelle. O Plutarco Brasileiro: a produção dos vultos nacionais no segundo império. Revista Estudos Históricos. v.14, n.25, p.41-62, 2000.

FEREIRA, Jorge. O governo Goulart e o golpe-civil militar de 1964. In: FEREIRA, Jorge; DELGADO, Lucilia de Almeida Neves. (Orgs) O Brasil Republicano (v. 3). Rio de Janeiro: Civ. Brasileira, 2003.

FICO, Carlos. Reinventando o otimismo: ditadura, propaganda e imaginação social no Brasil. Rio de Janeiro: FGV, 1997.

GAVA, José Estevam. Momento Bossa Nova: Arte e modernidade sob os olhares da Revista O Cruzeiro. Estudos em Jornalismo e Mídia, v. .2, n.1, p.134-146, 2005.

GONÇALVES, Márcia de Almeida. Em terreno movediço: biografia e história na obra de Octávio Tarquínio de Sousa. Rio de Janeiro: EdUERJ, 2009.

GUIMARÃES, Manoel Luiz Salgado. O presente do passado: as artes de Clio em tempos de memória. In: ABREU, Martha. SOIHET, Rachel. GONTIJO, Rebeca. (Orgs). Cultura política e leituras do passado: historiografia e ensino de história. Rio de Janeiro: Civilização Brasileira, 2007.

KOSSOY, Boris. Os tempos da fotografia: o efêmero e o perpétuo. Cotia, SP: Ateliê Editorial, 2007.

LE GOFF, Jacques. História e memória. Campinas: Editora da UNICAMP, 1990.

LIMA, Solange Ferraz de; CARVALHO, Vânia Carneiro. Fotografias: usos sociais e historiográficos. In: PINSKY, Carla Bassanezi; LUCA, Tania Regina de (Orgs). O historiador e suas fontes. São Paulo: Contexto, 2011.

NAPOLITANO, Marcos. A História depois do papel. In: PINSKY, Carla Bassanezi. Fontes históricas. São Paulo: Contexto, 2010.

NORA, Pierre. Entre memória e história: a problemática dos lugares. Projeto história: história e cultura, n. 10. São Paulo: Educ, 1993. 
ORLANDI, Eni Puccinelli. Vão surgindo sentidos. In: ORLANDI, Eni Puccinelli. (Org.) Discurso fundador: a formação do país e a construção da identidade nacional. Campinas: Pontes, 1993.

PACHECO, Ricardo de Aguiar. Cultura política: as mediações simbólicas do poder. In: PESAVENTO, Sandra Jatahy; SANTOS, Nádia Maria Weber; ROSSINI, Miriam de Souza.

(Orgs). Narrativas, imagens e práticas sociais: percursos em história cultural. Porto Alegre: Asterisco, 2008.

POLLAK, Michel. Memória, esquecimento, silêncio. Revista Estudos Históricos. Rio de Janeiro, v.2, n.3, p.03-15, 1989.

REIS FILHO, Daniel Aarão. O colapso do colapso do populismo ou a propósito de uma herança maldita. In FERREIRA, Jorge. (Org). O populismo e sua história: debate e crítica. Rio de Janeiro: Civilização Brasileira, 2001.

RYAN, Mary. A parada norte-americana: representações da ordem social do século XIX. In: HUNT, Lynn. A nova história cultural. São Paulo: Martins Fontes, 1992.

SCHWARCZ, Lilia Moritz. O espetáculo das raças: cientistas, instituições e a questão racial no Brasil. São Paulo: Cia. das Letras, 1993.

SERPA, Élio Cantalício. 1972: Sesquicentenário da independência: uma estética para a nação. Memória, poder e tecnologia. In: RAMOS, Alcides Freire; PATRIOTA, Rosangela; PESAVENTO, Sandra Jatahy (Orgs.). Imagens na história. São Paulo: Aderaldo \& Rothschild, 2008. p.213-232.

SETEMY, Adrianna Cristina Lopes. Em defesa da moral e dos bons costumes: a censura de periódicos no regime militar (1964-1985). Dissertação (mestrado) - Universidade Federal do Rio de Janeiro, Mestrado em História, Rio de Janeiro, 2008.

TURAZZI, Maria Inez. Quadros de história pátria: fotografia e cultura histórica oitocentista. In: FABRIS, Anneteresa. KERN, Maria Lúcia Bastos. (Orgs). Imagem e conhecimento. São Paulo: Ed. da USP, 2006.

\section{Fontes documentais:}

Revista Manchete. Ano 29, n.1045, Rio de Janeiro, 29 de abril de 1972.

Revista Manchete. Ano 29, n.1046, Rio de Janeiro, 6 de maio de 1972. 
Revista Manchete. Ano 29, n.1047, Rio de Janeiro, 13 de maio de 1972.

Revista Manchete - Edição da Independência: 150 Anos de Progresso. Rio de Janeiro, setembro de 1972.

Revista O Cruzeiro - Edição histórica de Sesquicentenário. Ano 44, n. 37. Rio de Janeiro, 13 de setembro de 1972. 